\title{
Potato Production in the Hot Tropical Areas of Africa: Progress Made in Breeding for Heat Tolerance
}

\author{
Jane Muthoni ${ }^{1} \&$ J. N. Kabira ${ }^{1}$ \\ ${ }^{1}$ Kenya Agricultural and Livestock Research Organization (KALRO), National Potato Research Centre, Tigoni, \\ Kenya \\ Correspondence: Jane Muthoni, Kenya Agricultural and Livestock Research Organization (KALRO), National \\ Potato Research Centre, Tigoni, Kenya. E-mail: jayney480@yahoo.com
}

Received: January 8, $2015 \quad$ Accepted: February 15, $2015 \quad$ Online Published: August 15, 2015
doi:10.5539/jas.v7n9p220
URL: http://dx.doi.org/10.5539/jas.v7n9p220

\begin{abstract}
Potato is a cool season crop and grows best between 15 and $18^{\circ} \mathrm{C}$ and soil $\mathrm{pH}$ of 5.5 to 6.0 . Temperatures above $21^{\circ} \mathrm{C}$ have adverse effects on growth. In tropical Africa, potato is grown in the highlands at altitudes between 1500 and 3500 meters above sea level. These areas are characterized by cool temperatures with high rainfall of at least $1000 \mathrm{~mm}$ per annum. With climate change, these highlands are rapidly warming up. In addition, the rapidly increasing population and consequent diminishing land sizes in these highlands have forced farmers to migrate to the lower, warmer and drier areas, where the migrants have moved with their cropping systems including the potato. Most of the tropical African countries are poor with an exploding population; there is need to come up with strategies to feed this population. Although a short duration crop such as potato can go a long way in solving the food crisis, most of the locally available potato varieties do not do well under high temperatures. Measures such as planting of heat-tolerant varieties and/or late maturing varieties as well as cultural practices such as mulching and changing the planting date may contribute to alleviating the situation. This review paper looks at breeding heat-tolerant potato varieties as a means for profitable production of potatoes in the hot tropical African region.
\end{abstract}

Keywords: heat-tolerant varieties, high temperature, potato production, tropical Africa

\section{Introduction}

High temperature is one of the most significant uncontrollable factors affecting potato yield and in the face of climate change, it is more important than ever to understand why potato yields can be so dramatically reduced by hot weather; new cultivars that are more resilient to high temperatures need to be developed. According to the Intergovernmental Panel of Climate Change (IPCC, 2007), global climate warming is an unequivocal fact. The IPCC (2007) predicted a rise in global temperature by $1.8-4{ }^{\circ} \mathrm{C}$ by the year 2100 . In addition, Africa will very likely (with $>90 \%$ probability) experience warming in greater measure than the global average in all seasons (Lobell \& Burke, 2010). Effects of global warming on potato production have been predicted to decrease yields by $10-19 \%$ in $2010-39$, and by $18-32 \%$ in the 2050 s; this is the time when more food is needed to feed the world's growing population (Hijmans, 2003; Hancock et al., 2013). The optimal yield for most commercial potato varieties is produced in average day time temperatures of $14-22^{\circ} \mathrm{C}$; higher temperatures lead to sharp yield decline. For example, at $27^{\circ} \mathrm{C}$, yield of variety Desiree plummeted to $0 \%$ while for Spunta it reduced to about $15 \%$ of maximum yields (Hancock et al., 2013).

Another significant threat posed by rising temperatures is water stress as transpiration rates in potato plants increase leading to greater demand from the soil. A rise in temperature leads to increased transpiration in plants thus raising their demand for water. In many of the drier potato growing regions, this will cause water stress, leading to further yield decline. The effect will be further aggravated by low and erratic rainfall resulting from climate change. Without adequate rainfall or irrigation systems, crop failure is a reality.

Depending on the temperature regime and the crop, high temperatures due to climate change can lead to low yields resulting from increased developmental rates and higher respiration. High developmental rates leads to a short growth cycle and this may result in low yield as the crop will have a short time to accumulate photoassimilates. However, a short growth cycle can also be beneficial, e.g., to escape drought or frost, and the use of late-maturing cultivars could offset the effect of high developmental rates. Furthermore, in environments 
where low temperatures now limit crop production, global warming could lead to a beneficial lengthening of the growing season and temperatures may rise close to optimal for crop production. Global warming is related to an increase of atmospheric carbon dioxide $\left(\mathrm{CO}_{2}\right)$ concentration which is likely to increase crop yields particularly when water shortage limits crop production (Nonhebel, 1993). Higher concentrations of atmospheric $\mathrm{CO}_{2}$, may actually benefit potatoes as increased $\mathrm{CO}_{2}$ stimulates the development of underground biomass in potato plants, with tuber weight and number both increasing significantly. Despite this, the real threat to potato production in the hot tropics is heat stress (Midmore, 1983).

The problem of high temperatures is more pronounced in tropical lowland zones where potential for potato production is heavily constrained by its sensitivity to heat (Hancock e al., 2013). Warm tropical environments are generally defined as those having a day length of $10-14$ hours, minimum night-time temperatures of $18-20^{\circ} \mathrm{C}$, mean maximum temperatures greater than $25^{\circ} \mathrm{C}$ and mean annual soil temperatures at $50 \mathrm{~cm}$ depth being $22^{\circ} \mathrm{C}$ or more (InfoResources, 2008). For several countries, particularly in tropical Africa, potato yield declines are expected to reach up to $20-30 \%$ (InfoResources, 2008). Tropical African countries are either least developed nations (LDCs) or developing nations (UNCTAD, 2013). These countries have agricultural-based economies. In addition, they have high and fast expanding populations which may be difficult to feed in the near future. Almost all of them do not have active potato breeding programmes and have been depending on the International Potato Center (CIP) for generation of advanced potato clones. Consequently, these countries are unlikely to have heat-tolerant varieties bred for their own specific localities because CIP has a more global mandate. These countries are therefore bound to experience high potato yield reduction due to high temperatures occasioned by climate change.

This review looks at the effects of high temperature on potato production in the hot tropical African region and progress made in breeding heat-tolerant varieties as a plausible coping mechanism.

\section{Effects of High Temperature on Potato Growth and Production}

Temperature is the single most important uncontrollable factor affecting growth and yield of potato (Smith, 1968). The potato has long been considered a cool weather crop best suited for the temperate climates although yields decline during the hot and dry seasons even in Europe, Americas and Australia (Gilbert, 1920). Temperature of $17^{\circ} \mathrm{C}$ has been defined as the optimum mean temperature for good yield in potatoes (Bushnell, 1925). Higher temperature may inhibit yield through overall reduction of plant development due to heat stress or by reduced partitioning of photoassimilates to tubers. The most important effect of high temperature is on the partitioning of assimilated carbon between leaves and tubers. More of assimilated carbon is partitioned to vegetative parts at high temperature while at lower night temperature most of the assimilated carbon is partitioned to the tubers (Wolf et al., 1990). A combination of high temperatures and long days favour assimilate partitioning to the above ground vegetative parts and as a result, above ground biomass and plant height is increased and tuber yield is reduced (Wolf et al., 1990). Therefore the main effect of high temperature is on assimilate partitioning and not on total plant productivity.

High temperature increases the rate of dark respiration in plants. Bushnell (1925) measured the rate of night respiration in potato plants at different temperatures and found doubling of respiration with every $10{ }^{\circ} \mathrm{C}$ increase in temperature. The optimum temperature for photosynthesis is about $25^{\circ} \mathrm{C}$. Above this temperature, the rate of photosynthesis decreases due to non-stomatal factors ( $\mathrm{Ku}$ et al., 1977). Three respiratory processes, i.e. photorespiration, growth respiration and maintenance respiration, change as a function of temperature along with the rate of photosynthesis. The effect of temperature on these processes is not necessarily to the same extent. This implies that low night temperature should result in less respiratory loss of photosynthates, thus making more photosynthates available for translocation to the developing tubers. Winkler (1971) reported a temperature optimum of 16 to $20{ }^{\circ} \mathrm{C}$ for potato production. He showed that dark respiration rates of potato leaves roughly doubled for each $10^{\circ} \mathrm{C}$ increase in temperature (Winkler, 1971). Burton (1981) assumed that where temperatures are in excess of $30^{\circ} \mathrm{C}$, net assimilation for potato falls to zero and yield reduction may occur.

Potato is grown in many different environments, but it is best adapted to temperate climates; it grows best between $15^{\circ} \mathrm{C}$ and $18^{\circ} \mathrm{C}$ (Haverkort, 1990; Haverkort et al., 1990; InfoResources, 2008). At high temperatures (above $17^{\circ} \mathrm{C}$ ) tuberisation diminishes (Reynolds \& Ewing, 1989). High temperatures delay, impede or even inhibit tuber initiation (Minhas et al., 2006). Potato tuber initiation and development are much more sensitive to high temperature stress than photosynthesis (Reynolds \& Ewing, 1989). Potato is also frost sensitive and severe damage may occur when temperature drops below $0{ }^{\circ} \mathrm{C}$ (Hijmans, 2003). In potato plants, high night temperatures are much more deleterious to the formation of tubers than day temperature. Minimum night temperature is very important for potato crop; whether or not potato will tuberise depends largely on the 
minimum night temperature and not on the average daily temperature (InfoResources, 2008). Tuberisation is reduced by night temperature of $20^{\circ} \mathrm{C}$ and there may not be any tuberisation at night temperature of $25^{\circ} \mathrm{C}$ and above even though potato plants can tolerate day temperature of about $35^{\circ} \mathrm{C}$ without much deleterious effects (Wolf et al., 1990; InfoResources, 2008). Night temperatures above $20^{\circ} \mathrm{C}$ severely depress both tuber initiation and bulking and temperatures above $25^{\circ} \mathrm{C}$ effectively stop tuber production (Minhas et al., 2001). Potato can give good yield even at day temperatures of $30-35^{\circ} \mathrm{C}$ provided night temperatures are below $18{ }^{\circ} \mathrm{C}$ (Minhas \& Kumar, 2005). But if night temperature go beyond $22^{\circ} \mathrm{C}$ there is very little tuberisation even when the day temperature is $25-27^{\circ} \mathrm{C}$. So heat tolerance in potatoes is concerned more with the minimum night temperature than the maximum day temperature (Burton, 1996; InfoResources, 2008). Previously, it was found that the optimum temperature for tuber formation is $20^{\circ} \mathrm{C}$ (Borah \& Milthorpe, 1962). In a previous study, it was found that at a lower temperature $\left(15^{\circ} \mathrm{C}\right)$ tuberisation was delayed by one week and at a higher temperature $\left(25^{\circ} \mathrm{C}\right)$ tuberisation was delayed by three weeks. The slower tuberisation at temperatures lower than $20^{\circ} \mathrm{C}$ probably resulted from slowed metabolism and growth, whereas the delayed tuberisation at $25^{\circ} \mathrm{C}$ was likely due to the specific inhibitory effects of the high temperature on the tuberisation process (Borah \& Milthorpe, 1962).

High temperature leads to development of tall plants with thin stems, small leaves, long stolons, increased number of inter-nodes, elongated internodes, inhibition of tuber development and a decrease in the ratio of tuber fresh weight to total fresh weight (Bodleander, 1963; Nagarajan \& Minhas, 1995). A low temperature, especially low night temperatures, increases the number of tubers per plant. The cooler temperatures result in delayed maturity which provides more time for the interception of solar radiation and the conversion of intercepted radiation to dry matter. At higher temperatures when fewer tubers per plant are formed, larger tubers are obtained. Although increases in either day or night temperatures above optimal levels reduce tuber yields, high night temperatures seem to be more deleterious (Gregory, 1956). Both high air temperature and high soil temperature cause yield reduction (Gregory, 1965). It has previously been found the optimum soil temperature is 15 to $18^{\circ} \mathrm{C}$ (Jones et al., 1922). Higher soil temperatures decreased tuber yields, especially when combined with high ambient air temperatures of $30^{\circ} \mathrm{C}$ day $/ 23^{\circ} \mathrm{C}$ night).

Tuber quality is also affected by high temperatures and some physiological tuber disorders are closely associated with heat stress and hot, dry weather (Ahmadi et al., 1960). Internal brown spots, also known as internal rust spots or chocolate spots which are manifested as necrotic brown spots in the tuber parenchyma are a response to high temperature. Heat necrosis, a brown discoloration in the vascular ring, occurs at high soil temperatures (Hooker, 1981). High temperatures may cause other tuber disorders including irregular tuber shape, chain tuberisation or secondary tuber formation (often associated with excessive stolon elongation and branching), sprouted tubers and reduced dry matter content (Bodleander, 1963). When high temperature stress was combined with drought stress under field conditions, tuber malformation and tuber sprouting were aggravated (Levy, 1986). High temperature during growth has been observed to increase the level of steroidal glycoalkaloids resulting in bitter tubers and a reduction in reducing sugars (Dimenstein et al., 1997). Heat stressed potato plants may have split shoots. This is most likely due to apical meristem being shocked from the heat and dying back. When this occurs, axillary buds will grow leading to multiple shoots. When plants are heat-stressed during developmental stage, they also develop knobs, second tubers, and sugar ends (Mendoza \& Estrada, 1979). High temperatures during tuber maturation may interfere with the onset of tuber dormancy, shorten the dormancy period, or even release the inhibition of tuber buds resulting in pre-harvest sprouting. This is likely associated with an increase of the endogenous content of growth-promoting substances such as gibberellins (Menzel, 1983).

High temperatures are associated with increase in pests such as nematodes and aphids as well as diseases such as bacterial wilt and viruses (Mendoza \& Estrada, 1979). Incidences of the most common viruses Potato Virus X (PVX), Potato Virus Y (PVY), Potato Virus S (PVS) and Potato Leaf Roll Virus (PLRV) may increase during dry weather when temperatures are high due to prevalence of vector aphids (CIP, 1975). Aphids are now common even in the highlands of Kenya due to climate change.

Differences in the response of various potato cultivars to temperature has been found (Levy, 1986). Solanum commersonii was found to have higher tuber yield at $25^{\circ} \mathrm{C}$ than at $12{ }^{\circ} \mathrm{C}$ indicating that certain Solanum species prefer higher temperatures and may be exploited as sources for heat tolerance (Davis, 1941). Wivutvongvana (1979) compared heat-tolerant and heat-sensitive clones of Solanum chacoense and Solanum acaule growing under non-tuberising long day photoperiod. Heat-sensitive clones were found to have higher rates of dark respiration than heat-tolerant clones but they did not differ in the rate of $\mathrm{CO}_{2}$ uptake during photosynthesis (Wivutvongvana, 1979). This suggests that tolerance to high temperatures may be associated more with differences in respiration than in photosynthesis. Other studies suggest that clones that have higher optimum temperatures for photosynthesis, or that maintain their photosynthetic activity at higher temperatures, as well as 
clones that maintain low rates of dark respiration at high temperature may be better suited for warm climates. Solanum juzepczukii was found to be more heat tolerant than S. tuberosum (Havaux, 1995). Incorporation of this tolerance could go along way in improving field performance of cultivated potato in the hot tropics.

\section{Coping Mechanisms}

Where there is no possibility of irrigation in hot tropical regions, potato yields will decrease even further to the extent where potato growing will become impossible altogether. Cultural practices such as shifting planting date may be used to avoid periods of high temperatures (Mendoza \& Estrada, 1979; Robert, 2003; David \& Richard, 2007). Effective use of planting date as an adaptation strategy, however, depends on reliable weather forecasts. Improving irrigation and early-warning systems for severe weather will become important adaptation strategies. Other cultural practices such as minimum tillage and mulching may also be considered. Use of mulches smoothens the diurnal variation in soil temperature particularly during dry season when solar radiation is high (Midmore, 1983). In addition, mulching can raise the organic matter content in the soil; this increases the soil's water holding capacity thus reducing runoff and erosion and making more water available to plants (InfoResources, 2008).

However, breeding heat-tolerant potato varieties maybe the best strategy to sustain and/or increase potato production in the hot tropics.

\subsection{Breeding for Heat Tolerance}

Heat tolerance in this context refers to the effect of temperature on tuberisation. Therefore, breeding for increased heat tolerance should focus on the effect of temperature on tuberisation since potato tuber initiation and development are much more sensitive to high temperature stress than photosynthesis (Haverkort et al., 2008). Identification or development of potato cultivars with increased heat tolerance appears to be important in coping with climate change (Hijmans, 2003). Relatively little is known about the genetic diversity for heat tolerance although there is genetic variability with respect to tuberisation at high temperature. Heat-tolerant accessions of several diploid species including S. berthaultii, S. chacoense, S. demissum, and S. stoloniferum among others have been identified (Reynolds \& Ewing, 1989). Introgression of such germplasm directly into S. tuberosum would require sexual polyploidization or breeding at the diploid level with dihaploids of $S$. tuberosum followed by tetraploidization through sexual polyploidization, somatic hybridization or artificial chromosome doubling.

Because heat stress tolerance is likely to be multigenic, understanding the basic physiological, biochemical and molecular responses to high temperatures can benefit breeding programmes aiming to develop heat tolerant potato varieties either by conventional targeted breeding or transgenic approaches (Hancock et al., 2013; Gangadhar et al., 2014). In potatoes, response to temperature is oligogenic with low temperature reaction being dominant over reaction to high temperature (Mendoza \& Estrada, 1979). Despite advances made in breeding heat-tolerant potatoes, molecular mechanisms governing heat-tolerance is poorly understood. The first step towards understanding the heat-tolerance mechanism is to identify the key genes involved in it (Gangadhar et al., 2014). Another problem is the medium to low heritability for yield, earliness and resistance or tolerance to stresses.

Aspects of heat tolerance that are considered important and should be taken into account in breeding programmes are: 1) ability of the plants to tuberise at night temperature of $22{ }^{\circ} \mathrm{C}$ and above, 2) low shoot/root ratio at high night temperature and 3) early maturity of the crop (Hijmans, 2003). Earliness does not necessarily need to be in the absolute sense of time from planting to senescence; a medium maturity cultivar with an early tuber initiation and fast bulking may also be suitable even if the vines do not reach maturity rapidly (CIP, 1975). A great deal of genetic variability for tuber initiation has been found and this trait may be rapidly improved through selection (CIP, 1975). Earliness obtained genetically may be enhanced to some extent through pre-sprouting of the tubers and planting seed of proper physiological age (CIP, 1975). Other desirable traits which should be included in the heat-tolerance breeding programmes are high water-use efficiency, increased root length, early maturity to escape heat and disease resistance (David \& Richard, 2007; InfoResources, 2008).

Various research institutions have been working hard to develop heat-tolerant potato varieties. A study by scientists at the James Hutton Institute, which aimed at identifying genetic markers for tolerance to heat stress could be of great importance in future breeding programmes to develop new potato cultivars that are less susceptible to high temperatures (Hancock et al., 2013). At the Scottish Crop Research Institute (SCRI) and Russian Potato Breeding Program, heat and drought tolerance is a major breeding objective (Raymundo et al., 2014). Research efforts at the Central Potato Research Institute in India has led to development of early maturing, heat tolerant variety, Kufri Sirya (Minhas et al., 2006). At the International Potato Center (CIP), high temperature was considered to be a primary cause of low yields in warm climates; this led to active breeding efforts to 
develop heat-tolerant clones.

At CIP, breeding for heat tolerance has been a target trait in breeding potatoes for developing countries since 1970s (Raymundo et al., 2014). As early as 1975, one of the major breeding thrust was to create populations that were superior in performance and stability for adaptation to the lowland tropics (CIP, 1975). From these breeding activities, 34 tetraploid clones were selected for earliness and high yield potential; these were later evaluated in Peru. It was also observed that during selection for adaptation to lowland tropics, the neo-tuberosum material was more responsive than $S$. tuberosum because the former had a broader genetic base (CIP, 1975). In addition, it appeared that the most promising materials for the lowland tropics had a $S$. tuberosum as one parent, which provides earliness and relative heat tolerance (CIP, 1975). Furthermore, to obtain highly heterotic hybrids, a neo-tuberosum or a Phueja-Stenotomum hybrid that produces $2 n$ gametes would be suitable as the other parent. In addition to the widening of the genetic base from such crosses, an adequate level of disease resistance is necessary 9CIP, 1975). Work at CIP aiming at developing improved germplasm and agronomic practices for potato production in warm tropical environments continued in the 1980s (Midmore \& Rhoades, 1987; Midmore et al., 1991; Midmore, 1992). The clones that were found to possess heat tolerance were those that initiated tuberisation under high temperatures, were more efficient in the conversion of intercepted radiation to dry matter under high temperatures and matured earlier than non tolerant clones. The breeding strategy involved increasing the frequency of genes controlling adaptation to heat, earliness and resistance or tolerance to biotic and abiotic stress. This was done through recurrent selection with progeny testing to identify superior progenitors. This is the most effective and practical way to breed potato at autotetraploid level due to complexities occasioned by its tetrasomic inheritance, high heterozygosity and asexual propagation (Sleper \& Poehlman, 2006). To breed heat tolerant clones, scientists at CIP used native Andean cultivars (S. andigena), the long day-adapted S. andigena (neo-tuberosum), cultivars and breeding lines mainly from Europe and USA (S. tuberosum), the diploid materials from Peru and USA (S. stenotomum and S. phureja) and others such as S. acaule, S. stoloniferum, S. demissum, $S$. sparsipilum, and S. raphanifolium (CIP, 2011). The CIP has recently been focusing on breeding short-season varieties (InfoResources, 2008). In addition to breeding efforts, CIP has also been developing methods of analysis and simulation models to improve projections regarding the impact of climate change on potato production as well as specific adaptation measures. These include, for example, recommendations regarding cultivation methods for sustainable potato production which are aimed at enhancing the capacity of potato production systems to react to the impacts of climate change.

Some disease resistant varieties derived from heat tolerant progenitors released in Africa were: Ingabire, Muruta, Muziranzara and Ruzinko in Burundi; IRA- 92 and Cipira in Cameroon; Kinga and Meva in Madagascar; Kinigi, Mabondo and Mizero in Rwanda as well as Victoria and Kisoro in Uganda (ADU, 2008). Other heat - tolerant clones that have been developed by CIP include 392797.22 (released as UNICA in Peru), 720148, 397077.16 (released as Sarnay), 397029.21, 397035.26, and 390478.99 (CIP, 2010; 2011).

\section{Recommendations}

In the hot tropics, local potato breeding initiatives should be spurred so as to develop and promote locally adapted heat tolerant varieties. In addition to heat tolerance, the locally developed varieties need to be high yielding and resistant to local pests and diseases while meeting the local market needs for domestic consumption and processing.

\section{References}

ADU. (2008). Catalogue of potato varieties. Acquisation and Distribution Unit. Centro Internacional de la Papa, Lima, Peru.

Ahmadi, A. A., Mobarak, H., \& Osguthorpe, K. (1960). The effect of time of planting on occurrence of internal brown spot in potato variety Arran Banner in Lebanon. American Potato Journal, 37, 23-27. http://dx.doi.org/10.1007/BF02855588

Bodleander, K. B. A. (1963). Influence of temperature, radiation and photoperiod in development and yield. In J. D. Ivins \& F. L. Milthorpe (Eds.), The Growth of the Potato (pp. 199-210). Butterworth, London, UK.

Borah, M. N., \& Milthorpe, F. L. (1962). Growth of the potato as influenced by temperature. Indian Journal of Plant Physiology, 5, 53-72.

Burton, W. G. (1996). Yield and content of dry matter: 1-The underlying physiological processes. In W. G. Burton (Ed.), The Potato (pp. 84-155). Longman Scientific and Technical, Essex, England.

Bushnell, J. (1925). The relation of temperature to growth and respiration in the potato plant. Minnesota Agricultural Experiment Station Technical Bulletin, 34, 29. 
CIP. (1975). Annual Report of 1975. Centro Internacional de la Papa. Lima, Peru.

CIP. (2010). Enhanced food and income security in Southwest and Central Asia (SWCA) through potato varieties with improved tolerance to abiotic stress. Centro Internacional de la Papa, Lima, Peru. Retrieved December 20, 2014, from http://cipotato.org/press-room/press-releases/beating-the-heat-of-global-warming/\#sthash.ak xEBgP8.dpuf

CIP. (2011). Beating the heat of global warming. Centro internacional de la papa, Lima, Peru. Retrieved December 20, 2014, from http://cipotato.org/press-room/press-releases/beating-the-heat-of-global-warming

David, L., \& Richard, E. (2007). Adaptation of potato to high temperatures and salinity. American Journal of Potato Research, 84, 487-506. http://dx.doi.org/10.1007/BF02987885

Davis, G. E. (1941). The effects of certain environmental factors on tuberization in the wild potato Solanum commersonii. American Potato Journal, 18, 266 -269. http://dx.doi.org/10.1007/BF02892051

Dimenstein, L., Lisker, N., Kedar, N., \& Levy, D. (1997). Changes in the content of steroidal glycoalkaloids in potato tubers grown in the field and in the greenhouse under different conditions of light, temperature and daylength. Physiological and Molecular Plant Pathology, 150, 391-402. http://dx.doi.org/10.1006/pmpp.1997.0098

Gangadhar, B. H., Yu, J. W., Sajeesh, K., \& Park, S. W. (2014). A systematic exploration of high-temperature stress-responsive genes in potato using large-scale yeast functional screening. Molecular Genetics and Genomics, 289, 185-201. http://dx.doi.org/10.1007/s00438-013-0795-z

Gilbert, A. W. (1920). The Potato. MacMillan Co. New York.

Gregory, L. E. (1956). Some factors for tuberization in the potato plant. American Journal of Botany, 43, 281-288. http://dx.doi.org/10.2307/2438945

Gregory, L. E. (1965). Physiology of tuberization in plants. Encyclopedia of Plant Physiology, 15, $1328-1354$.

Hancock, R. D., Morris, W. L., Ducreux, L. J. M., Morris, J. A., Usman, M., Verrall, S. R., ... Taylor, M. A. (2013). Physiological, biochemical and molecular responses of the potato (Solanum tuberosum L.) plant to moderately elevated temperature. Plant Cell and Environment, 37(2), 439-450. http://dx.doi.org/10.1111/pce.12168

Havaux, M. (1995). Temperature sensitivity of the photochenfical function of photosynthesis in potato (Solanum tuberosuon) and a cultivated Andean hybrid (Solarium xjuzepczukii). Journal of Plant Physiology, 146, 47-53. http://dx.doi.org/10.1016/S0176-1617(11)81966-8

Haverkort, A. J. (1990). Ecology of potato cropping systems in relation to latitude and altitude. Agricultural Systems, 32, 251-272. http://dx.doi.org/10.1016/0308-521X(90)90004-A

Haverkort, A. J., van de Waart, M., \& Bodlaender, K. B. A. (1990). The effect of early drought stress on numbers of tubers and stolons of potato in controlled and field conditions. Potato Research, 33, 89-96. http://dx.doi.org/10.1007/BF02358133

Haverkort, A. J., Boonekamp, P. M., Hutten, R., Jacobsen, E., Lotz, L. A. P., Kessel, G. J. T., ... van der Vossen, E. A. G. (2008). Societal costs of late blight in potato and prospects of durable resistance through cisgenic modification. Potato Research, 51, 47-57. http://dx.doi.org/10.1007/s11540-008-9089-y

Hijmans, R. J. (2003). The effect of climate change on global potato production. American Journal of Potato Research, 80, 271-280. http://dx.doi.org/10.1007/BF02855363

Hooker, W. J. (Ed.). (1981). Compendium of potato diseases. American Phytopathological Society, St. Paul, Minnesota.

InfoResources. (2008). Potatoes and climate change. Länggasse 85, 3052 Zollikofen, Switzerland. Retrieved January 10, 2015, from http://www.inforesources.ch

IPCC. (2007). IPCC Fourth Assessment Report 2007. Working Group II Report "Impacts, Adaptation and Vulnerability". Intergovernmental Panel on Climate Change. Retrieved January 10, 2015, from http://www.ipcc-wg2.org

Jones, L. R., McKinney, H. H., \& Fellows, H. (1922). Wisconsin Agricultural Experimental Station. Bulletin No 53.

KARI. (2008). Production of food (ware) potatoes. KARI information brochure. Kenya Agricultural Research Institute, Nairobi, Kenya. 
Ku, S. B., Edwards, G. E., \& Tanner, C. B. (1977). Effect of light, carbon dioxide and temperature on photosynthesis, oxygen inhibition of photosynthesis and transpiration in potato. Plant Physiology, 59, 868-872. http://dx.doi.org/10.1104/pp.59.5.868

Levy, D. (1986). Genotypic variation in the response of potatoes (Solanum tuberosum L.) to high ambient temperatures and water deficit. Field Crops Research, 15, 85-96. http://dx.doi.org/10.1016/0378-4290(86)90103-6

Lobell, D., \& Burke, M. (2010). Climate change and food security: Adapting agriculture to a warmer world. Advances in Global Change Research 37. Springer Science +Business Media. Springer Dordrecht, Heidelberg, London, New York. http://dx.doi.org/10.1007/978-90-481-2953-9

Mendoza, H. A., \& Estrada, R. N. (1979). Breeding potatoes for tolerance to stress: Heat and frost. In H. Mussell \& R. C. Staples (Eds.), Stress physiology in crop plants (pp. 227-262). John Wlley \& Sons, New York.

Menzel, C. M. (1983). Tuberisation in potato (Solanum tuberosum cultivar Sebago) at high temperature: gibberellin contents and transport from buds. Annals of Botany, 52, 697-702.

Midmore, D. J. (1983). The use of mulch for potatoes in the hot tropics. CIP Circular (Vol. 2 No. 1). Centro Internacional de la Papa, Lima, Peru.

Midmore, D. J. (1992). Potato production in the tropics. In P. Harris (Ed.), The Potato Crop: The Scientific Basis for Improvement (2nd ed.). Chapman and Hall, London, UK. http://dx.doi.org/10.1007/978-94-011-2340-2_15

Midmore, D. J., \& Rhoades, R. E. (1987). Applications of agrometeorology to the production of potato in the warm tropics. Acta Horticulturae, 215, 103-136.

Midmore, D. J., Ekanayake, I. J., Benz, J. S., \& Payton, F. V. (1991). Contribution of recent physiological studies to the improvement of potato production in warm climates. In N. Govinden, M. H. R. Julien, G. L. T. Hunt, \& L. J. C. Autrey (Eds.), Production, Post-harvest Technology and Utilization of Potato in the Warm Tropics (pp. 45-51). Proceedings of a Workshop, July 23-27, 1990, Réduit, Mauritius. Mauritius Sugar Industry Research Institute, Reduit, Mauritius.

Minhas, J. S., \& Kumar, D. (2005). Tuberization in heat tolerant hybrid HT/92-621 under controlled temperature conditions. Potato Journal, 32, 195-196.

Minhas, J. S., Singh, B., Kumar, D., Joseph, T. A., \& Prasad, K. S. K. (2001). Selection of heat tolerant potato genotypes and their performance under heat stress. Journal of Indian Potato Association, 28, 132-134.

Minhas, J. S., Kumar, D., Joseph, T. A., Raj, B. T., Khurana, S. M. P., Pandey, S. K., ... Naik, P. S. (2006). Kufri Surya: A new heat-tolerant potato variety suitable for early planting in North-western plains, peninsular India and processing into french fries and chips. Potato Journal, 33, 35-43.

Nagarajan, S., \& Minhas, J. S. (1995). Intemodal elongation: A potential screening technique for heat tolerance in potato. Potato Research, 38, 179-186. http://dx.doi.org/10.1007/BF02357931

Nonhebel, S. (1993). The importance of weather data in crop growth simulation models and assessment of climatic change effects (Ph.D. thesis, Wageningen Agricultural Uiiiversity, Wageningen, Netherlands).

Raymundo, R., Kleinwechter, U., \& Asseng, S. (2014). Virtual potato crop modeling: A comparison of genetic coefficients of the DSSAT-SUBSTOR potato model with breeding goals for developing countries.

Reynolds, M. P., \& Ewing, E. E. (1989). Effects of high air and soil temperature stress on growth and tuberization in Solanum tuberosum. Annals of Botany, 64, 241-247.

Robert, J. H. (2003). The effect of climate change on global potato production. American Journal of Potato Research, 80, 271-280. http://dx.doi.org/10.1007/BF02855363

Sleper, D. A., \& Poehlman, J. M. (2006). Breeding field crops (5th ed.). Blackwell Publishing Professional. 2121 State Avenue, Ames, Iowa.

Smith, O. (1968). Potatoes: Production, storing, processing. The Avi Publishing Company, Inc., Westport, Connecticut.

UNCTAD. (2013). UN list of least developed countries. United Nations Conference on Trade and Development, Geneva, Switzerland. Retrieved January 6, 2015, from http://unctad.org/en/pages/aldc/Least\%20Developed $\% 20$ Countries/UN-list-of-Least-Developed-Countries

Winkler, E. (1971). Kartoffelbau in Tirol. II. Photosynthese vermogen und respiration yon verschiedenen 
kartoffelsorten. Potato Research, 14, 1-18. http://dx.doi.org/10.1007/BF02355914

Wivutvongvana, M. (1979). Physiological response of heat tolerant and heat sensitive potatoes (Solanum species) (Ph.D. Dissertation, Cornell University, Ithaca, New York, USA).

Wolf, S., Marani, A., \& Rudich, A. (1990). Effects of temperature and photoperiod on assimilate partitioning in potato plants. Annals of Botany, 66, 513-520.

\section{Copyrights}

Copyright for this article is retained by the author(s), with first publication rights granted to the journal.

This is an open-access article distributed under the terms and conditions of the Creative Commons Attribution license (http://creativecommons.org/licenses/by/3.0/). 